\title{
Mucosal complement deposition in inflammatory bowel disease
}

\author{
Trond S Halstensen, MD, PhD, LiIPAT, Per Brandtzaeg, PhD
}

TS HALSTENSEN, P BRANDTZAEG. Mucosal complement deposition in inflammatory bowel disease. Can J Gastroenterol 1993;7(2):91-101. Mucosal deposition of activated complement and immunoglobulin (Ig) in inflammatory bowel disease (IBD) was examined by indirect two- and three-colour immunofluorescence staining applied on sections of ethanol-fixed or frozen tissue specimens from patients with ulcerative colitis or Crohn's disease. Monoclonal antibodies (mAbs) to $\operatorname{lgG}$ subclasses and neoepitopes of activated $\mathrm{C} 3 \mathrm{~b}$ or terminal complement complex (TCC) were used in combination with rabbit antiserum to various complement components $(\mathrm{Clq}, \mathrm{C} 3 \mathrm{c}, \mathrm{C} 3 \mathrm{dg}, \mathrm{C} 4 \mathrm{c})$. Activated $\mathrm{C} 3 \mathrm{~b}$ was found on the luminal face of the surface epithelium in the most affected ulcerative colitis specimens from $91 \%$ of 23 patients, together with cytolytic TCC in $8.1 \%$. Similar deposition was observed in $50 \%$ of 18 patients with Crohn's disease. However, co-deposition of the $\mathrm{IgGl}$ subclass and complement components involved in the classical activation pathway (Clq and $\mathrm{C} 4 \mathrm{c}$ ) was seen only in ulcerative colitis and in complement components involved in the classical activation pathway $(\mathrm{Clq}$ and $\mathrm{C} 4 \mathrm{c}$ ). Moreover, in ulcerative colitis these epithelial immune complexes often co-localized with a previously identified $\mathrm{M}_{\mathrm{r}} 40 \mathrm{kDa}$ putative autoantigen (mAb $7 \mathrm{E}_{12} \mathrm{H}_{12}$ ). Additional type $\mathrm{III}$ immune reaction might take place in both diseases because evidence of continuous vascular complement activation has been seen in submucosal blood vessels. The results demonstrated that local complement activation takes place in IBD lesions. While epithelial deposition of $\mathrm{IgGl}$ and activated complement suggested an autoimmune attack in ulcerative colitis, the absence of $\mathrm{IgGl}, \mathrm{Clq}$ and $\mathrm{C} 4 \mathrm{c}$ in Crohn's disease was rather consistent with the alternative activation pathway.

Key Words: Activated complement, Complement deposition, IBD, Pathogenesis

\section{Dépôt du complément au niveau de la muqueuse dans la}

\section{maladie intestinale inflammatoire}

RÉSUMÉ: Les dépôts de complément et d'immunoglobuline (Ig) activés au niveau muqueux dans la maladie intestinale inflammatoire ont été examinés à laide d'une coloration indirecte par immunofluorescence à deux et à trois couleurs, effectuée sur des sections de spécimens de tissu congelés ou fixés à l'éthanol obtenu de patients porteurs de maladie de Crohn ou de colite ulcéreuse. Les anticorps monoclonaux dirigés contre des sous-classes d'IgG et de nouveaux déterminants génétiques de $\mathrm{C} 3 \mathrm{~b}$ activés ou le complexe de complément terminal ont été utilisés en combinaison avec des antiséra de lapin sur différentes com-

Laboratory for Immunohistochemistry and Immunopathology, Institute of Pathology,

University of Oslo, The National Hospital, Rikshospitalet, Oslo, Norway

Correspondence and reprints: Dr TS Halstensen, Rikshospitalet, N-0027, Oslo, Norway.

Telephone (47-2) 86-86-30/35/27, Fax (47-2) 11-22-61

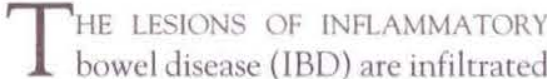
with lymphocytes, macrophages, immunoglobulin ( $\mathrm{Ig}$ )-producing plasma cells (mainly of the complement activating $\lg$ G1 subclass) and a striking accumulation of neutrophils (1-3). These features suggest that local complement activation takes part in the pathogenesis.

Complement system: Complement is a complex multifactorial defence system composed of at least 26 soluble and membrane-bound proteins with the potential of forming an activated cascade. Such activation may be induced by complexing $\operatorname{IgG}$ or $\operatorname{IgM}$ antibodies with luminal or epithelial antigens (classical pathway) (Figure 1), or by direct activation of $\mathrm{C} 3$ by components of the local microbiota (alternative pathway) (4). Both pathways induce C3 cleavage and merge in the terminal activation step with the assembly of the terminal complement complex (TCC), ie, C5b-9 (5-7).

Classical activation pathway: The classical pathway components consist of the $\mathrm{C} 1$ complex (Clqrs), C2 and C4. This pathway is activated by binding of Clqrs with the Fc portion of $\operatorname{IgG}$ or $\mathrm{IgM}$ bound to antigen. $\lg \mathrm{M}$ has a superior activation potential and of the IgG subclasses, IgG3 seems to be more potent than IgG1. The complement-activating potential of $\mathrm{IgG2}$ is somewhat controversial, but may depend on antigen density (8). $\operatorname{IgG} 4$ (9), $\lg A(10)$ and $\lg E$ (11) do not activate human complement by the classical pathway. Ac- 
posantes du complément $(\mathrm{Clq}, \mathrm{C} 3 \mathrm{c}, \mathrm{C} 3 \mathrm{dg}, \mathrm{C} 4 \mathrm{c})$. Le C3b activé a été observé sur la face luminale de l'épithélium de surface des spécimens de colite ulcéreuse les plus touchés de $91 \%$ des 23 patients, le complexe de complément terminal cytolytique étant présent chez $8,1 \%$. Un dépôt similaire a été observé chez $50 \%$ des 18 patients atteints de maladie de Crohn. Cependant, le dépôt conjoint d'une sous-classe d'IgGl et de composantes du complément associées à la voie d'activation classiques $(\mathrm{Clq}$ et $\mathrm{C} 4 \mathrm{c})$. De plus, dans la colite ulcéreuse, ces complexes immuns épithéliaux se trouvaient localisés avec un autoantigène $\mathrm{Mt}$ $40 \mathrm{kDa}$ possiblement déjà identifié (mAb 7E12H12). Une autre réaction immunitaire de type III peut avoir lieu dans les deux maladies parce que l'on observe une activation continue du complément vasculaire dans les vaisseaux sanguins sous-muqueux. Nos résultats ont démontré que l'activation du complément local a lieu dans des lésions de la maladie intestinale inflammatoire. Bien que les dépôts épithéliaux d'IgG1 et l'activation du complément suggèrent une attaque autoimmune dans la colite ulcéreuse, l'absence d'IgG1, de Clq et de C4c dans la maladie de Crohn concorde plutôt avec la voie d'activation alternative.

tivated $\mathrm{Cl}$ catalyzes the assembly of the classical C3 convertase, C4b2a (12). Complement activation may be controlled at this stage by the $\mathrm{C} 4 \mathrm{~b}$-binding protein (C4bp) or factor I in plasma and by complement receptor 1 , decay-ac-

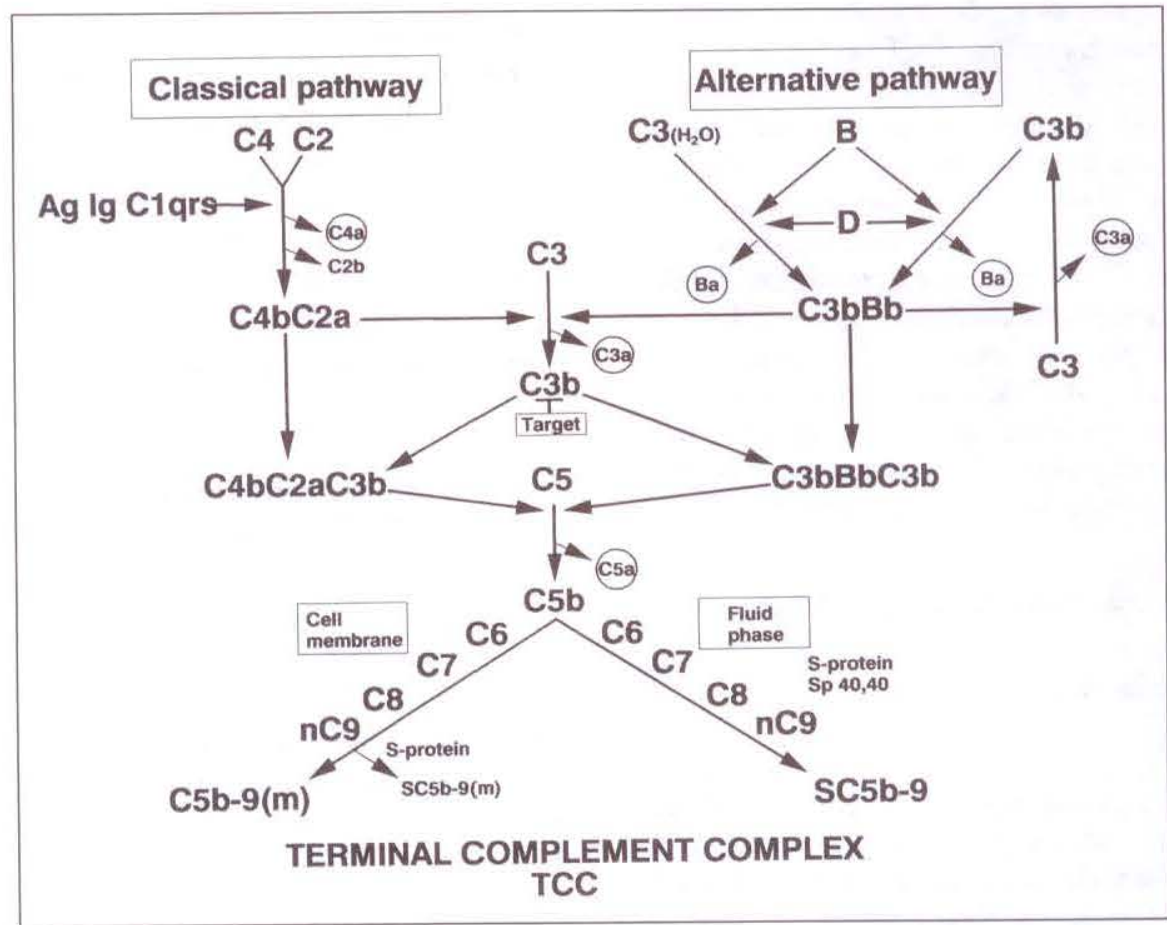

Figure 1) Schematic depiction of various complement activation steps. Classical pathway is antibody-dependent; alternative pathway is induced by various components of the target surface (for details see text). Both pathways produce the $\mathrm{C} 3$ convertases $\mathrm{C} 4 \mathrm{~b} \mathrm{C} 2 \mathrm{a}$ and $\mathrm{C} 3 \mathrm{bB}$, respectively, which cleave $\mathrm{C} 3$ to yield $\mathrm{C} 3 a$ and $\mathrm{C} 3 b$. The latter split product binds to the $\mathrm{C} 3$ convertases and participates in $\mathrm{C} 5$ cleavage, which initiates terminal pathway activation by generation of $\mathrm{C} 5 a$ and $\mathrm{C} 5 \mathrm{~b}$. The C $3 b$ reacts with $\mathrm{C} 6, \mathrm{C} 7, \mathrm{C} 8$ and $\mathrm{C} 9$ to form terminal complement complex (TCC). On biological membranes, TCC is generated as the cytolytic (pore-forming) C $5 b-9(m)$. Conversely, in the fluid phase (ie, in plasma or interstitial tissue fluid) S protein or Sp 40,40 (clusterin) binds to TCC at the $\mathrm{C} 5 b-7$ level and cytolytically inactive soluble SC5b-9 results. S-protein may also be present in membrane-incorporated TCC as SC $5 b-9(m)(30)$
Ig. It consists of four serum proteins: $\mathrm{C} 3$, factor B, factor D and properdin $(14,15)$.

The alternative pathway is, in fact, always active. Spontaneous hydrolysis of the internal thioester bond in $\mathrm{C} 3$ generates a modified C3b-like molecule, $\mathrm{C} 3(\mathrm{H} 2 \mathrm{O})$, which may associate with factor $\mathrm{B}$. The $\mathrm{C} 3(\mathrm{H} 2 \mathrm{O}) \mathrm{B}$ complex is activated by factor $D$ and factor $\mathrm{B}$ is cleaved into $\mathrm{Ba}$ and $\mathrm{Bb}$. The product $\mathrm{C} 3(\mathrm{H} 2 \mathrm{O}) \mathrm{Bb}$ is the alternative pathway by which $\mathrm{C} 3$ convertase cleaves $\mathrm{C} 3$; the anaphylatoxin $\mathrm{C} 3 \mathrm{a}$ is released and $\mathrm{C} 3 \mathrm{~b}$ binds covalently to the target with its very reactive thioester bond. Regardless whether $\mathrm{C} 3 \mathrm{~b}$ is generated by the classical or alternative pathway, it may bind another factor $B$, thereby activating the alternative amplification loop, or bind to factor $\mathrm{H}$ and be cleaved by factor $\mathrm{I}$, which terminates further activation (Figure 2) $(16,17)$. It is the nature of the surface that determines whether $\mathrm{C} 3 \mathrm{~b}$ preferentially binds to factor $\mathrm{B}$ or to the inhibitory factor $\mathrm{H}$. Factor $\mathrm{P}$ is not essential for the alternative pathway but stabilizes the alternative $\mathrm{C} 3$ convertase, resulting in more efficient activation.

The two activation pathways are not strictly separated because antibodies and immune complexes may also activate the alternative pathway (18), and agents (such as cardiolipin, C-reactive protein and bacterial surface antigens) may activate the classical pathway under certain circumstances (18-22).

Terminal activation pathway: When target-bound $\mathrm{C} 3$ convertase $(\mathrm{C} 4 \mathrm{bC} 2 \mathrm{a}$ or $\mathrm{C} 3 \mathrm{bBb}$ ) binds its own product ( $\mathrm{C} 3 \mathrm{~b}$ ), it becomes the $\mathrm{C} 5$ convertase, which initiates terminal pathway activation by generating $\mathrm{C} 5 \mathrm{a}$ and $\mathrm{C} 5 \mathrm{~b}$. Whether surface-bound or in the fluid phase, $\mathrm{C} 5 \mathrm{~b}$ reacts with $\mathrm{C} 6, \mathrm{C} 7, \mathrm{C} 8$ and $\mathrm{C} 9$ to form TCC. When C7 binds to C5b-6 on biological membranes, it exposes hydrophobic regions and becomes inserted into the lipid bilayer. Thereafter $\mathrm{C} 8$ and $\mathrm{C} 9$ bind to $\mathrm{C} 5 \mathrm{~b}-\mathrm{C} 7$. The lytic activity of the $\mathrm{C} 5 \mathrm{~b}-8$ complex is limited to erythrocytes, whereas killing of nucleated cells requires at least one C9 within the membrane-bound TCC 
(C5b-9[m]) (23). Two membrane molecules have been shown to inhibit TCC formation on cell membranes: the homologous restriction factor (24), also called C8-binding protein (C8bp) (25), and the $\mathrm{Mr}_{\mathrm{r}} 20 \mathrm{kDa}$ homologous restriction factor (CD59) $(26,27)$.

When the terminal pathway is activated in the fluid phase (ie, in plasma or intestinal tissue fluid), the $\mathrm{S}$ protein (vitronectin) and/or $\mathrm{Sp} \mathrm{40,40} \mathrm{(clus-}$ terin) binds to TCC at the C5b-7 level; cytolytically inactive soluble SC 5 b-9 is generated $(28,29)$. S protein was previously named 'serum spreading factor' because it promotes adhesion of cells to extracellular substrates. Small amounts of $\mathrm{S}$ protein may also be present in membrane-incorporated TCC (SC5b$9[\mathrm{~m}])(30)$.

$\mathrm{C} 3 \mathrm{~b}$ inactivation: $\mathrm{C} 3 \mathrm{~b}$ - bound to either complement receptor 1 or 2 (CR1 or CR2) or serum factor $\mathrm{H}$ becomes partly degraded by serum factor $\mathrm{I}$, and a small $\mathrm{M}_{\mathrm{r}} 2 \mathrm{kDa}$ fragment $\mathrm{C} 3 \mathrm{f}$ is released from the $\alpha$ chain (Figure 2) (31-33). The inactivated product (iC3b) is degraded to a small $\mathrm{M}_{\mathrm{r}} 40$ $\mathrm{kDa}$ fragment, $\mathrm{C} 3 \mathrm{dg}$, and a major $\mathrm{M}_{\mathrm{r}}$ $150 \mathrm{kDa}$ fragment, $\mathrm{C} 3 \mathrm{c}$. The latter is released to the fluid phase whereas C3dg (which contains the C3b thioester bond) remains covalently bound to the target surface (34). C3dg may be further cleaved by trypsin to C3d $\left(\mathrm{M}_{\mathrm{r}} 30 \mathrm{kDa}\right)$ and $\mathrm{C} 3 \mathrm{~g}\left(\mathrm{M}_{\mathrm{r}} 10\right.$ $k D E)$ in vitro (35).

Neoepitopes in the complement system: The structural alteration of complement components induced during activation exposes new antigenic determinants (eg, monoclonal antibodies [mAbs]) to neoepitops; these react selectively with the activated components and can therefore be used for immunohistochemistry on directly fixed or frozen tissue to reveal in situ complement activation.

The $\mathrm{mAb}$ bH6 reacts with a neoepitope in the $\mathrm{C} 3 \mathrm{c}$ part of $\mathrm{C} 3 \mathrm{~b}$ or with its inactivated form iC3b (36). Terminal activation may be disclosed by $\mathrm{mAb}$ aEll reacting with a $\mathrm{C} 9$ neoepitope exposed during C9 polymerization in membrane-incorporated TCC (C5b-9[m]) or when C9 binds to $\mathrm{C} 8$ in the soluble $\mathrm{S}$ protein-

\section{REGULATION OF C3-ACTIVATION}

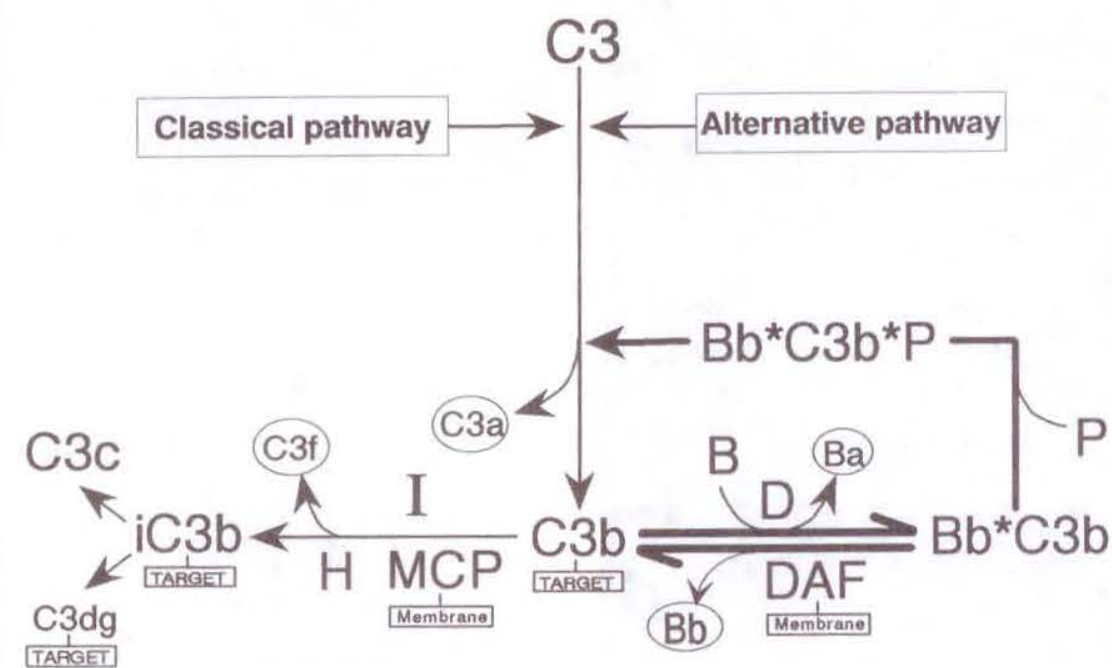

Inactivation

Figure 2) Schematic depiction of $\mathrm{C} 3$ activation and regulation. When $\mathrm{C} 3$ is activated either by the immunoglobulin $(\mathrm{Ig})$-dependent classical or the Ig-independent alternative pathway, the anaphylatoxin $\mathrm{C} 3 \mathrm{a}$ is released and $\mathrm{C} 3$ b becomes covalently bound to the target. The physicochemical properties of surface determines the fate of target-bound $C 3 b$. It may either bind factor $B(B)$, which induces the amplification loop, or it may be inactivated if bound to factor $\mathrm{H}$ or membrane cofactor protein $(M C P)$ and cleaved by factor $I(I)$. The complex $C 3 b^{*} B$ is activated by factor D (D) and $\mathrm{B} a$ is released to the fluid face. The product $\mathrm{B} b^{*} \mathrm{C} 3 b$, also named the alternative pathway $\mathrm{C} 3$ convertase, can activate $\mathrm{C} 3$ alone, but factor $\mathrm{P}(\mathrm{P})$ stabilizes the complex, leading to prolonged activation. Conversely, cells that express decay accelerating factor (DAF) and MCP (like vascular endothelium) will rapidly inactivate the complex. While DAF releases factor $B b$ from the complex, MCP binds to $\mathrm{C} 3 b$ and acts as a cofactor for factor $I$. The small fragment $\mathrm{C} 3 f$ is first released and the inactivated form of $\mathrm{C} 3 b$ ( $i \mathrm{C} 3 b)$ is cleaved further to form $\mathrm{C} 3 c$ (released to the fluid face) and the small fragment $\mathrm{C} 3 \mathrm{dg}$ (remains attached to the target)

bound form of TCC (SC5b-9) (37). These two forms of TCC, therefore, cannot be distinguished by $\mathrm{mAb}$ aEll.

Previous immunohistochemical studies of complement deposition in IBD were based on antisera to native complement components applied on tissue specimens that contained unpredictable amounts of extracellular serum proteins $(38,39)$. In fact, there may be quite high concentrations of interstitial native $\mathrm{C} 3$ in inflamed tissue with increased vascular permeability (40).

The purpose of the authors' previous studies $(41-45)$ has been to trace the site and nature of mucosal complement activation in IBD. In addition, we reexamined the tissue distribution of the previously identified $\mathrm{M}_{\mathrm{r}} 40 \mathrm{kDa}$ putative autoantigen in ulcerative colitis $(46,47)$ by using the $m A b 7 E_{12} \mathrm{H}_{12}$ for immunofluorescence two- and threecolour staining.

\section{MATERIALS AND METHODS}

Tissue and immunological reagents: The clinical material consisted of colonic biopsy or resection specimens from 39 patients with ulcerative colitis, 18 with Crohn's colitis, and 26 controls (mainly histologically normal mucosa from patients with colonic carcinoma). Ileal samples from 14 patients with Crohn's ileitis and six controls were also included.

Immunohistochemical staining for $\operatorname{IgG}$ and complement on directly fixed tissue specimens may represent retained extravascular serum proteins rather than immune complexes (40). To overcome this problem, the authors used extensively prewashed specimens 


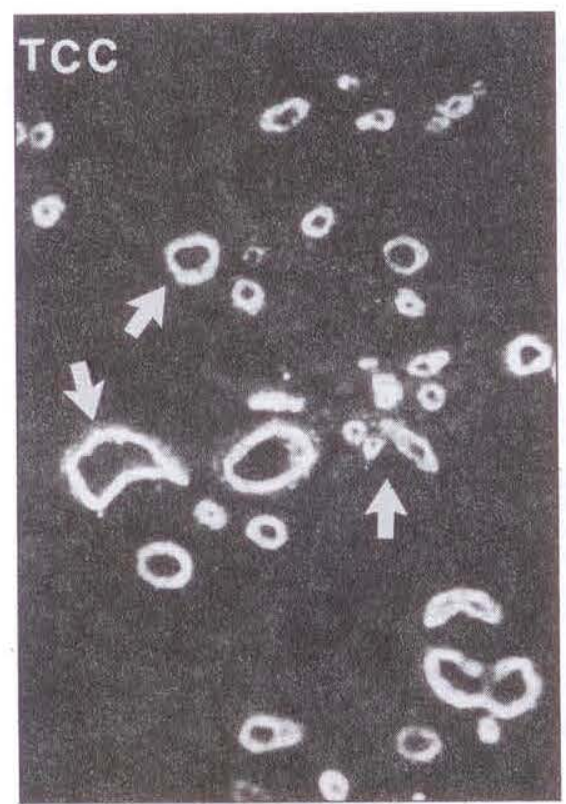

Figure 3) Intense staining for the terminal complement complex (TCC) was observed in vessel walls (arrows). Prewashed, ethanol-fixed and paraffin-embedded colonic specimen from a patient with active ulcerative colitis is shown. (original magnification $\times 44$ )

from which most diffusible extracellular proteins, such as $\lg G$ and complement, had been extracted (48). In addition, $\mathrm{mAbs}$ specific for neoepitopes of activated complement were used on both prewashed and directly ethanolfixed and paraffin-embedded specimens to resolve whether the observed deposits represented tissue-bound or soluble immune complexes. Additional tissue specimens were immediately placed in ice-chilled tissue culture medium (RPMI 1640, Gibco, Paisley, Scotland) or in a $0.5 \%$ to $1 \%$ paraformaldehyde-lysine-periodate fixative and brought to the laboratory within 2 $\mathrm{h}$. The biopsy specimens were properly oriented on a thin slice of carrot, embedded in optimum cutting temperature (Tissue-Tek, Miles Laboratories, Indiana), snap-frozen in isopenthane cooled in liquid nitrogen and stored at $-70^{\circ} \mathrm{C}$ until cryosectioning $(4 \mu \mathrm{m})$ (45).

Dewaxed paraffine sections $(6 \mu \mathrm{m})$ were incubated with $\mathrm{mAb}$ to a $\mathrm{C} 3 \mathrm{c}$ neoepitope exposed in $\mathrm{C} 3 \mathrm{~b}$, iC $3 \mathrm{~b}$ and $\mathrm{C} 3 \mathrm{c}$ (C3b-neo, mAb bH6), (36), a C9 neoepitope in TCC (mAb aE11) (37) or $\mathrm{S}$ protein (Cytotech, California) in

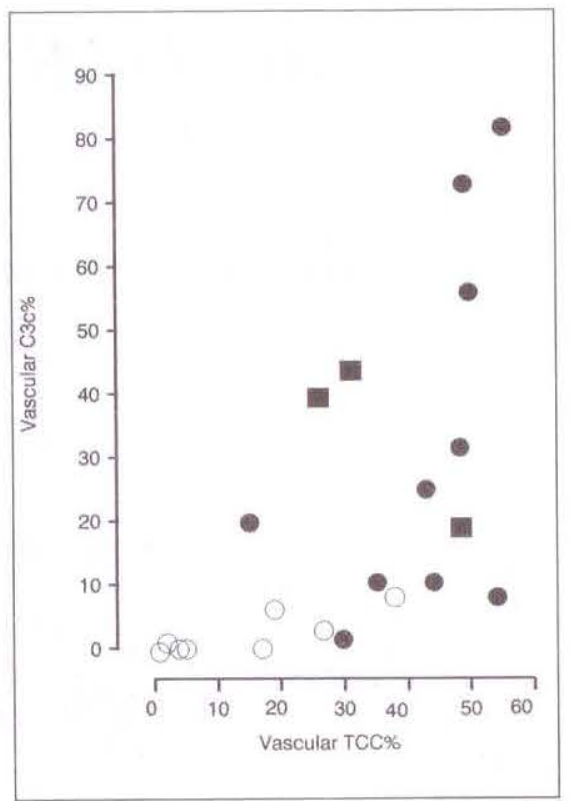

Figure 4) Scatter plot of vascular terminal complement complex\% (TCC\%) versus $\mathrm{C} 3 \mathrm{c} \%$. The two variables were well correlated $(P<0.005$, Kendall's $\tau=0.57)$. Controls $O$; Ulcerative colitis : Crohn's disease of the colon

combination with rabbit antiserum to C1q (1:500, Dakopatts, Glostrup, Denmark), C3c (1:500, Behringwerke AG, Marburg, Germany), C3d, C4c and C5 (all 1:500, Dakopatts), C9 (1:500, Behringwerke $A G)$, cytokeratin (1:100) (49), von Willebrandt factor (1:350, Dakopatts) or S protein (1:5000) (50). A three-step two-colour biotin/avidinenhanced immunofluorescence staining procedure was principally performed as described previously (51). Sections from prewashed tissue were, in addition, examined with $\mathrm{mAbs}$ to the four IgG subclasses: (clones: 267, GO M2, CBI-AH7, RJ4, respectively) (52) in combination with rabbit antiserum to $\mathrm{C} 3 \mathrm{c}$ and $\mathrm{C} 4 \mathrm{c}$.

Because inflamed tissue contains more vessels than normal tissue, vascular $\mathrm{TCC}$ and $\mathrm{C} 3 \mathrm{c}$ positivity was scored on a semiquantitative scale and related to the number of blood vessels in the actual section. Each specimen was given a vascular TCC and $\mathrm{C} 3 \mathrm{c}$ percentage score as detailed elsewhere (42). With regard to epithelial deposits, a semiquantitative score was applied for each immunological marker ranging from no epithelial staining (-) to in- tense staining on many epithelial cells $(3+)$. Histopathological examination was performed to grade each specimen with regard to inflammation from negative (-) to intense $(3+)$.

Three-colour immunofluorescence staining: Selected colonic and ileal specimens from five patients with Crohn's disease and five with ulcerative colitis having apical complement deposition (see below) were subjected to three colour staining in which $\mathrm{mAb}$ to human IgG1 (murine IgG1) was combined with $\mathrm{mAb} b \mathrm{bH} 6$ to $\mathrm{C} 3 \mathrm{~b}$ (IgG2a) or mAb aEll to TCC (IgG2a) and mixed with rabbit antiserum to $\mathrm{C} 3 \mathrm{c}$ or $\mathrm{C} 4 \mathrm{c}$. Secondary reagents were biotinylated and FITC-conjugated subclass-specific goat antimouse IgG2a and IgG1 (Southern Biotechnology, Alabama) followed by 7-amino-4. methylcoumarin-3-acetic acid (AMCA)-conjugated goat antirabbit IgG (1:20, Vector Laboratories, location) in combination with Streptavidin-Texas Red $(0.0025 \mathrm{~g} / \mathrm{L}$; Bethesda Research Laboratories, Gaithersburg, Maryland).

Additional sections of selected eth. anol-fixed and paraffin-embedded or paraformaldehyde-lysine-periodate-fixed cryosections from ulcerative colitis patients were likewise subjected to three-colour staining; the murine $\operatorname{IgM} \mathrm{mAb} 7 \mathrm{E}_{12} \mathrm{H}_{12}$ to the $\mathrm{M}_{\mathrm{r}} 40$ $\mathrm{kDa}$ colonic protein was mixed with rabbit antiserum to cytokeratin and combined with either $\mathrm{mAb} b \mathrm{~b} 6$ to $\mathrm{C} 3 \mathrm{~b}$ (murine IgG2a), mAb aEll to TCC (IgG2a) or $\mathrm{mAb}$ to human IgG1. Preselected saline-extracted and ethanol-fixed specimens from five ulcerative colitis patients were also subjected to three-colour staining in which the murine $\mathrm{IgM}$ mAb $7 \mathrm{E}_{12} \mathrm{H}_{12}$ was combined with $\mathrm{mAb}$ to $\operatorname{IgG} 1$ and rabbit antiserum to $\mathrm{C} 3 \mathrm{c}$. Secondary reagents were biotinylated goat subclass-specific antimouse $\mathrm{IgG} 1$ or $\lg \mathrm{g} 2 \mathrm{a}$ (0.01 gL) (Southern Biotechnology) combined with FITC-conjugated goat class-specific antimouse IgM $(0.05 \mathrm{gL})$ (Southern Biotechnology). Both com binations were applied for $1 \mathrm{~h}$ and were followed by incubation ( 30 mins) with AMCA-conjugated goat antirabbit $\operatorname{IgG}(1: 10)$ (Vector Laboratories, Bur- 

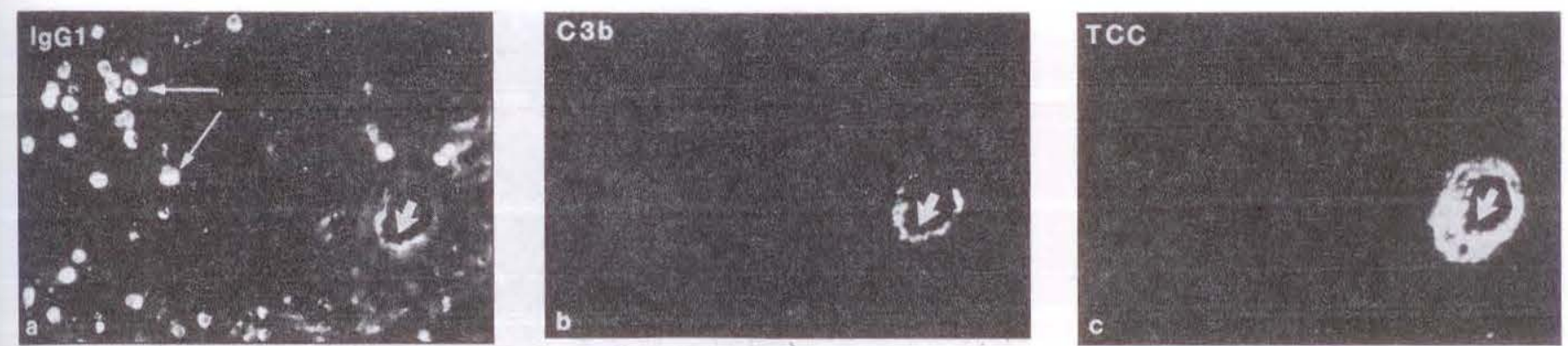

Figure 5)Three-colour staining for (a) immunoglobulin (Ig) G1 (b) C3b (c) terminal complement complex (TCC) in submucosal vessel from patient with Crohn's disease of the colon shoving segmental staining for immunoglobulin Gl associated with the complement deposition (arrow). The same vessel also contained Clqand C4c (not shown), suggesting classical pathway activation. The section is from a prewashed ethanol-fixed and paraffin-embedded colonic specimen from a patient with Crohn's disease of the colon (original magnification $\times 106$ )

lingame, California) in combination with Streptavidin-Texas Red $(0.0025$ gL).

The intestinal distribution of the $\mathrm{M}_{\mathrm{r}}$ $40 \mathrm{kDa}$ putative autoantigen in ulcerative colitis was examined on formalinfixed and paraffin-embedded routine tissues blocks from various levels of normal gastrointestinal fractions. Twocolour immunofluorescence staining combining the $m A b 7 E_{12} \mathrm{H}_{12}$ to the $\mathrm{M}_{\mathrm{r}}$ $40 \mathrm{kDa}$-antigen with rabbit serum to cytokeratin was performed as described above.

\section{RESULTS}

Vascular terminal complement complex deposits: There was significantly more $(\mathrm{P}<0.01)$ complement deposition (C3d and TCC) in the colonic submucosal blood vessels from patients with IBD than in controls (Figure 3). The median TCC percentage increased from $11 \%$ in controls to $31 \%$ in ulcerative colitis and to $46 \%$ in Crohn's colitis. Some of the TCC-positive vessels showed segmental co-staining for $\mathrm{C} 3 \mathrm{~b}$ (C3b-neo and $\mathrm{C} 3 \mathrm{c}$ ). The median $\mathrm{C} 3 \mathrm{c}$ percentage ( $1 \%$ in controls) increased to $23 \%$ in ulcerative colitis and to $39 \%$ in Crohn's colitis. There was good correlation between the $\mathrm{C} 3 \mathrm{c}$ and TCC percentages (Kendall's $\tau=0.57$, $\mathrm{P}<0.0005$ ) (Figure 4).

The vascular complement deposits did not generally contain detectable $\mathrm{Ig}$ components. However, submucosal vessels in two patients with Crohn's colitis contained C1q, C3b, C4c, TCC and weak segmental $\operatorname{lgGl}$ positivity (Figure 5).

Diverse complement positivity: Subepithelial deposition of TCC, S protein and C3d was often observed in affected specimens from both diseases. Some specimens of all categories contained
C3d and TCC, associated with S protein-positive elastic fibrils in the lamina muscularis mucosae, submucosa and perivascular sheets, although such staining was observed more often and with more intensity in IBD patients than in controls. The contents of fissure ulcers and crypt abscesses stained for C3d and TCC, but were mostly negative for C3b. The follicular dendritic cells in the germinal centres stained for C3d, TCC and S protein, but not for $\mathrm{C} 3 \mathrm{~b}$. This feature was observed in normal and diseased colon and was similar to that seen in normal lymphoid tissue (53). Numerous cells in the lamina propria contained cytoplasmic granules that stained for $\mathrm{C} 3 \mathrm{c}, \mathrm{C} 4 \mathrm{c}, \mathrm{Clq}$ and occasional IgG1 (Figure 6).

Distribution of the $\mathrm{M}_{\mathrm{r}} 40 \mathrm{kDa}$ antigen in the normal gastrointestinal tract: The $\mathrm{mAb} 7 \mathrm{E}_{12} \mathrm{H}_{12}$ did not react with epithelium of esophagus, stomach,
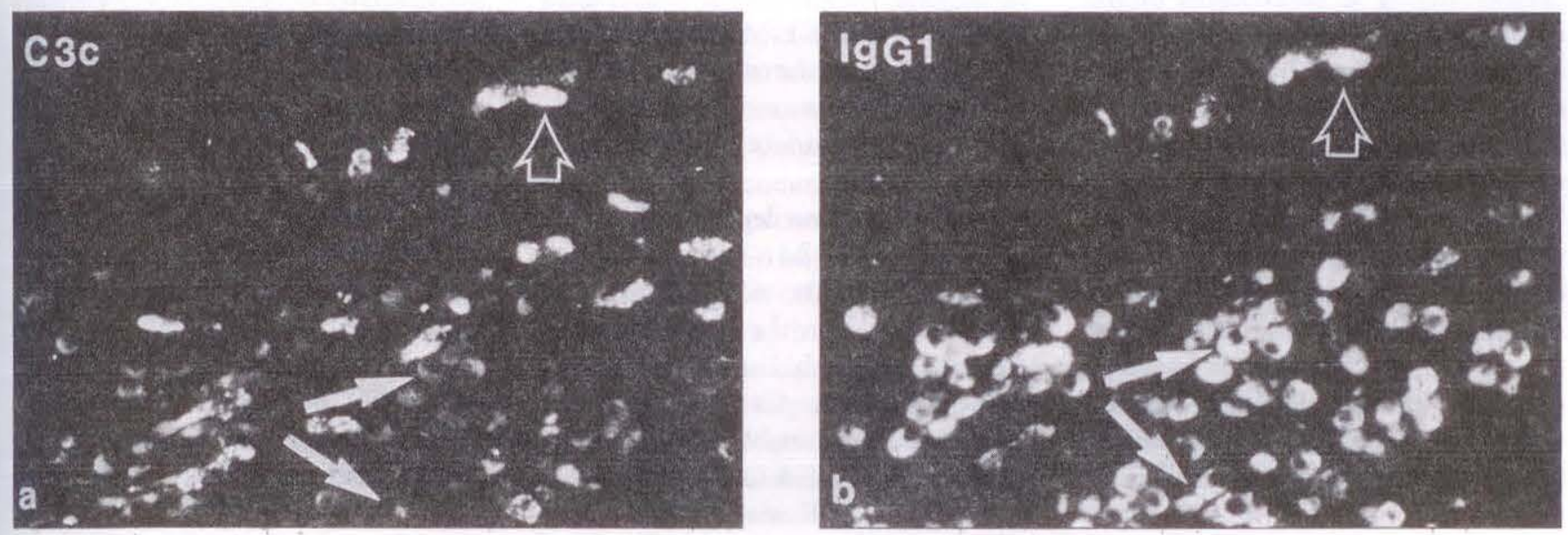

Figure 6) Two-colour staining for (a) C3c and (b) immunoglobulin ( $\mathrm{gg}$ ) G1 in the submucosa from a patient with ulcerative colitis. Note many lgGl-producing plasma cells (arrows) and some cells with cytoplasmic granules containing both IgGI and C3c (open arrow) (possibly immune-complexcontaining macrophages). Section from prewashed, ethanol-fixed and paraffin-embedded colonic specimen from a patient with active ulcerative colitis (original magnification $\times 106$ ) 

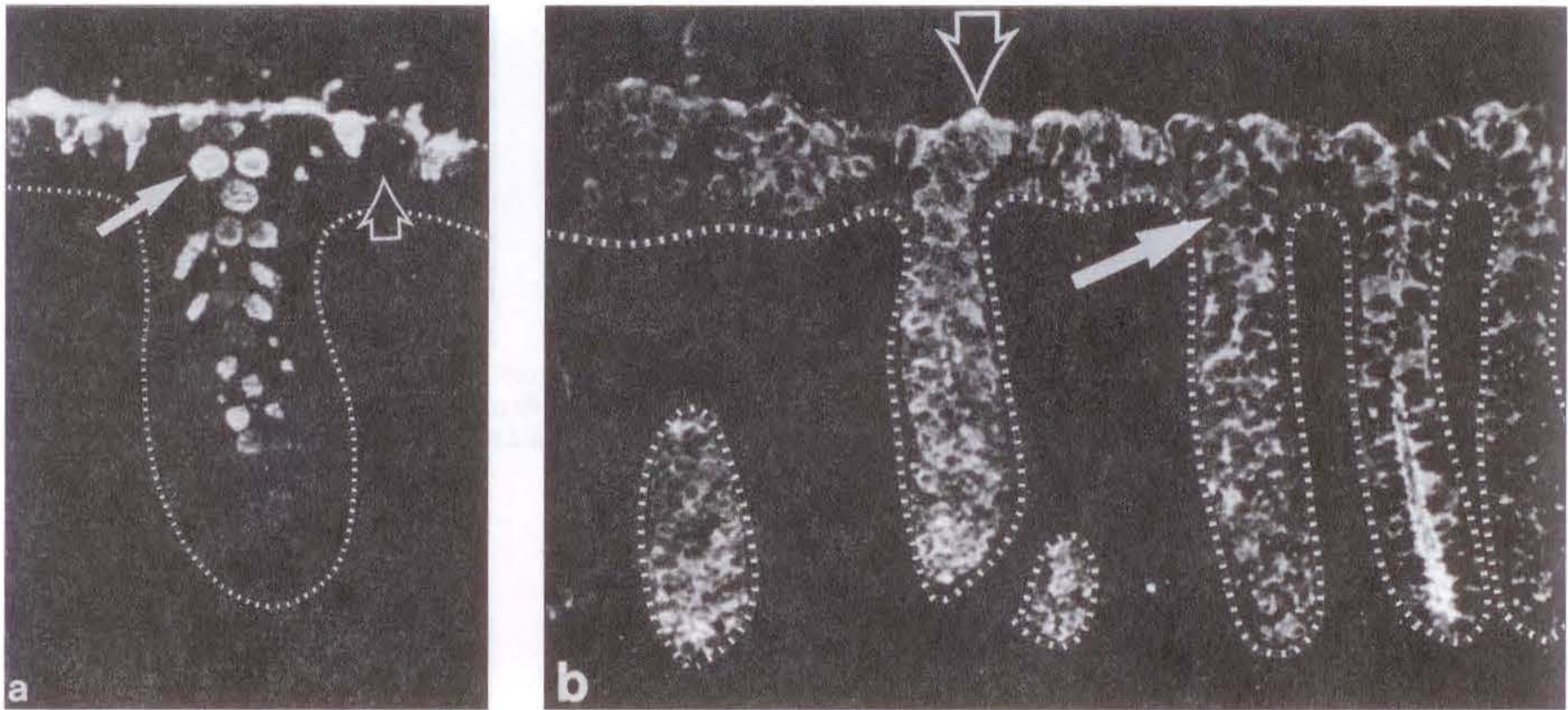

Figure 7) Immunofluorescence staining for the $\mathrm{M}_{\mathrm{r}} 40 \mathrm{kDa}\left(\mathrm{mAb} 7 \mathrm{E}_{12} \mathrm{H}_{12}\right)$ in (a) ascending colon (X44) and (b) rectum ( $\left.\mathrm{x} 106\right)$ on section of formalin-fixed routine specimens from control colon (x106). Whereas goblet cells are selectively stained in the ascending colon, they are virtually negative in the rectum (closed arrow). Enterocytes, however, are intensely stained in the rectum but not in the ascending colon (open arrows). Dashed line indicates epithelial basement membrane zone

duodenum or proximal jejunum. The enterocytes of jejunum and ileum (including the terminal ileum) also did not react. Occasional goblet cells with strong staining were observed in ileal crypts of specimens taken about $110 \mathrm{~cm}$ proximal to the cecum. The frequency of such positive goblet cells appeared to increase in distal direction; many crypt goblet cells in the terminal ileum were stained. In the cecum and ascending colon, most goblet cells were positive as was the apical face of surface epithelium (Figure 7a). The enterocytes of the colon increased their apical cytoplasmic staining in distal direction, and the crypt and surface enterocytes of the rectum were usually intensely positive throughout the cytoplasm (Figure 7b). The goblet cell staining was unaltered in the transverse and descending colon but decreased in the sigmoid and virtually vanished in the normal rectum (Figure 7b).

Epithelial immune deposits - ulcerative colitis: $\mathrm{C} 3 \mathrm{~L}$ was observed on the colonic surface epithelium in $91 \%$ of the 23 ulcerative colitis patients studied; $81 \%$ of these patients had cytolytic TCC deposited within the C3b. Both the frequency (Figure 8 ) and the intensity (Kendall's $\tau=0.56, P<0.001$ ) of immune deposition were well correlated with the topical degree of inflammation.

Because colon-specific autoantibodies have been reported in IBD (54. $60)$, the authors examined prewashed tissue specimens from 11 ulcerative colitis and 19 Crohn's colitis patients for co-deposition of complement components and $\lg$ subclasses. Patients with ulcerative colitis $(63 \%)$ showed selective binding of IgG1 apically on colonic epithelial cells; C3b and TCC often were present within these IgG1 deposits (Figure 9). Moreover, the $\mathrm{M}_{\mathrm{r}}$ $40 \mathrm{kDa}$ putative autoantigen co-localized with the immune complexes apically on the surface epithelium in ulcerative colitis.

Epithelial immune deposits - Crohn's disease: Somewhat more granular epithelial deposits of C3b and TCC were observed on the luminal face of the surface epithelium in 10 of 18 patients with Crohn's colitis. Specimens from eight of 14 patients with ileal involvement showed intense staining for $\mathrm{C} 3 \mathrm{~b}$ within the surface mucus layer. No epithelial IgG, C1q or $\mathrm{C} 4 \mathrm{c}$ deposition was detected in Crohn's disease (Figure 10), contrasting the codeposition of IgG1, C3b, C4c, TCC and, occasionally, Clq observed in ulcerative colitis. Additional globular elements with membrane positivity for $\mathrm{C} 3 \mathrm{~b}$ were seen attached to the epithelium in one-half of the Crohn's patients; aggregates of C3b-positive globular elements were seen in the lamina propria in directly fixed specimens from three patients.

The ileal surface mucin stained for $\mathrm{C} 3 \mathrm{~b}$ in eight of 14 patients with Crohn's disease, four of whom also stained for TCC on the apical face of the epithelium. Epithelial complement deposits were not seen in $96 \%$ of 26 colonic controls, nor in six ileal controls. Epithelial deposition of IgG was not observed in any control.

\section{DISCUSSION}

Vascular complement activation: Vas. cular complement deposits are usually regarded as a sign of immune complex formation, often associated with vas. culitis (61). However, the authors ob. served no cellular infiltration or fibrinoid necrosis along with TCC or $\mathrm{C} 3 \mathrm{~b}$, although thrombosed submucosal vessels positive for $\mathrm{TCC}$ and $\mathrm{C} 3 \mathrm{~b}$ were seen in two patients (42). The vascular TCC was apparently in a membranebound form because it was retained after 
extensive prewashing of the tissue specimens, suggesting that it represented the lytic, membrane-incorporated C5b-9 $(\mathrm{m})$. However, there was a striking co-localization of TCC and S protein, suggesting that it represented the soluble $\mathrm{S}$ protein-associated form of TCC (42). Nevertheless, the possibility for soluble SC5b-9 (passively retained from the circulation) was apparently excluded by the extensive washing procedure applied, which removed most diffusible molecules of comparable size (eg, IgM, $\mathrm{M}_{\mathrm{r}} 1000 \mathrm{kDa}$ ) from the tissue. Another possibility was an $\mathrm{S}$ proteinvitronectin-mediated binding of SC $5 b$ 9 to $S$ protein receptors on fibroblasts or/and smooth muscle cells in the vascular walls (62), but this apparently was contradicted by the parallel staining for TCC and C3d, suggesting that both early and late phase complement activation had occurred in situ. Moreover, the vascular immune deposits in ulcerative colitis, and especially in Crohn's disease, contained significantly more $\mathrm{C} 3 \mathrm{~b}$ than control colon.

Because breakdown of $\mathrm{C} 3 \mathrm{~b}$ is a rapid process, the presence of both $\mathrm{C} 3 \mathrm{~b}$ and TCC suggested that vascular complement activation is a continuous process in IBD. Although the vascular immune deposits did not generally stain for $\mathrm{lg}$ (63), segmental co-deposition of $\operatorname{IgG1}$, $\mathrm{Clq}$ and $\mathrm{C} 4 \mathrm{c}$ in $\mathrm{C} 3 \mathrm{~b}$ - and TCC-positive vessels observed in two samples from Crohn's colitis suggested antibody-mediated classical activation (12).

Hemorrhagic necrosis induced by a local Shwartzman's reaction depends on both $\mathrm{C} 5 \mathrm{a}$ and tumour necrosis factor (64). Complement activation might initiate this reaction as $\mathrm{C} 5$ a stimulates macrophages to tumour necrosis factor transcription (65). Such activity could induce thrombosis of submucosal vessels in IBD, and larger vessels are probably involved in Crohn's disease because of the transmural inflammation; perhaps this explains why vascular thrombosis and intestinal infarction seem to be a feature of Crohn's disease (66). The diffuse C3b positivity observed in the mucin layer of patients with Crohn's ileitis might reflect increased local synthesis and external

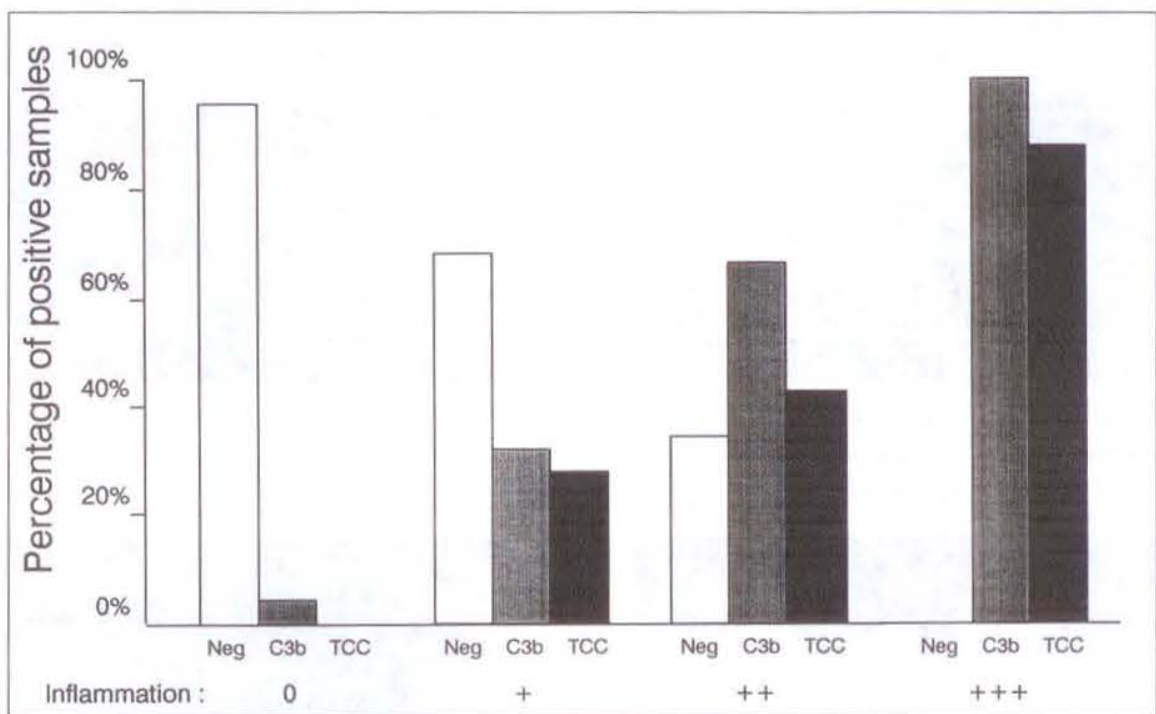

Figure 8) Epithelial complement deposits in ulcerative colitis. Percentage of specimens with epithelial $\mathrm{C} 3 \mathrm{~b}$ and terminal complement complex (TCC) deposition in relation to actual severity of inflammation in ulcerative colitis (range 0 to +++ ). All specimens with intense $(3+)$ inflammation showed epithelial C3b deposition. Neg Negative

transfer of $\mathrm{C} 3$, as was shown recently to take place even in unaffected mucosa in this disease (67).

Epithelial IgG1 and complement deposition: The epithelial deposition of IgG1 along with activated complement $(\mathrm{C} 4 \mathrm{c}, \mathrm{C} 3 \mathrm{~b}$ and $\mathrm{TCC})$ in active ulcerative colitis could reflect binding of autoantibodies to brush border-associated antigen(s) and complementmediated epithelial attack $(43,44)$. This was further supported by the frequent co-localization of the epithelial immune complexes and the $M_{r} 40 \mathrm{kDa}$ colonic protein, which has previously been proposed to be an autoantigen in ulcerative colitis (45-47).

The expression of this antigen, also observed in ileal mucin (45), might explain 'backwash ileitis' (68) and ileal pouchitis (69), commonly seen in ulcerative colitis patients. The colonic distribution of the $M_{r} 40 \mathrm{kDa}$ antigen, from mainly goblet cell positivity in the proximal colon to increasing enterocyte expression in the distal direction, further supports its putative role as an autoantigen in ulcerative colitis. Moreover, the mAb to the $\mathrm{M}_{\mathrm{r}} 40 \mathrm{kDa}$ antigen and the classical serum anticolon antibodies (60) produce a similar staining pattern in human and rat colon, and ulcerative colitis patients have serum antibodies to both the $\mathrm{M}_{\mathrm{r}} 40 \mathrm{kDa}$ antigen (70) and rat colon extracts (54); this suggests that the $M_{r} 40 \mathrm{kDa}$ protein may be associated with the antigen for the classical anticolon antibodies.

Although epithelial cells are partly protected against autologous complement attack by $\operatorname{CD} 59(71,72)$, this survival mechanism may not be sufficient in IBD mucosa. The enterocytes will probably also try to escape IgGmediated complement attack by rapid shedding of damaged plasma membranes (73). This event may involve loss of the epithelial brush border in ulcerative colitis; the putative consequence is reduced surface area and hampered absorptive function. Epithelial damage, in addition, will increase leakage of autoantibodies and complement components into the colonic lumen where transport takes place distally. Because the putative autoantigen is located at the apical surface, epithelium located downstream may be subjected to an IgG1-mediated complement attack continuously. Perhaps this explains why ulcerative colitis is typically a continuum in distal direction. In addition, autoantibodies may complex with mucin-associated antigen and cause luminal complement activation. The anaphylatoxins $(\mathrm{C} 4 \mathrm{a}$, $\mathrm{C} 3 \mathrm{a}, \mathrm{C} 5 \mathrm{a}$ ) produced may contribute to 

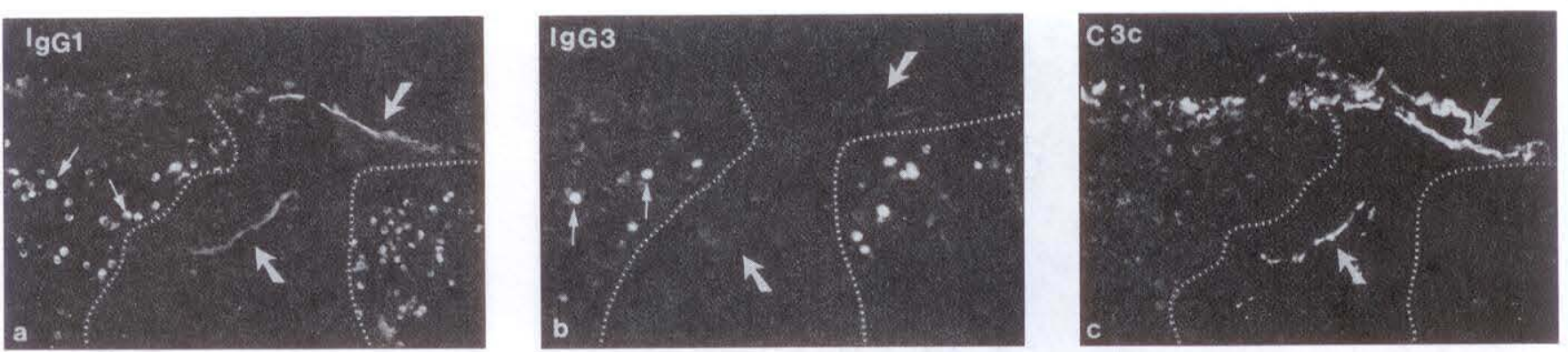

Figure 9) Immunofluorescence staining for (a) immunoglobulin (Ig) G1, (b) IgG3 and (c) activated C3b umarker C3cin section of extensively prewashed colonic mucosa from a patient with ulcerative colitis. Small arrows indacate plasma cells producing IgG3. Only IgG1 was deposited on the apical surface of the epithelium, often in conjugation with $\mathrm{C} 3 \mathrm{~b}$ (large arrows). Dashed lines indicate epithelial basement membrane zone (original magnification $\mathrm{x} 100)$
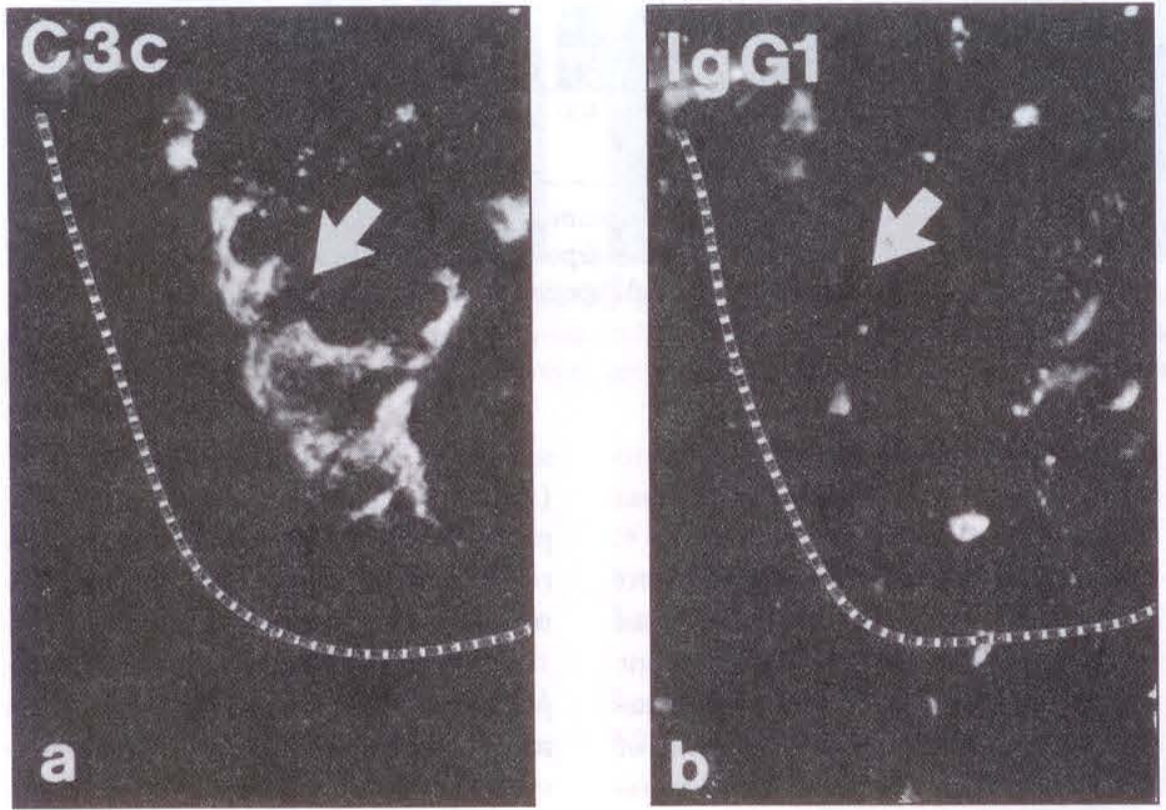

Figure 10) Two-colour immunofluorescence staining for a immunoglobulin G1 and b activated complement $\mathrm{C} 3 \mathrm{c}$ in section of extensively prewashed colonic mucosa from patient with Crohn's disease of the colon. No immunoglobulin (Ig) GI (or any other IgG subclass) was observed within the $\mathrm{C} 3$ b-positive epithelial deposits in Crohn's disease (arrows). Dashed lines indicate epithelial basement membrane zone (original magnification $\times 100$ )

transepithelial migration, activation and degranulation of granulocytes in active ulcerative colitis.

Epithelial complement deposition is not specific for ulcerative colitis; it was also observed in approximately onehalf of patients with Crohn's colitis (44). However, lack of co-deposition of $\lg \mathrm{G}$ and classical complement activation pathway components $(\mathrm{Clq}$ and C4c) suggests that complement was activated by the alternative pathway in Crohn's disease.

Subepithelial deposition of TCC, S protein and C3d, was mainly seen directly beneath or adjacent to epithelial destruction in ulcerative colitis (43), but also under intact epithelium in Crohn's disease (44). Although this might be a secondary phenomenon, soluble immune complexes generated in the basement membrane zone could have induced subepithelial complement activation. The possibility that the $\mathrm{C} 3 \mathrm{~b}$-positive globular elements observed in mucosa with Crohn's colitis represented bacteria, such as those previously identified by electron microscopy in this lesion $(74,75)$ or the isolated wall-deficient spheroblasts of Mycobacterium paratuberculosis (76), needs further elucidation.

Consequences of mucosal complement activation: Regardless of the mode of complement activation and the nature of the target attacked, generation of the anaphylatoxins (C3a, C4a and $\mathrm{C} 5 \mathrm{a}$ ) causes inflammation and release of other inflammatory mediators such as leukotrienes and prostaglandins (77. 83 ). The elevated levels of these substances found in the ulcerative colitis lesion (84-86) could therefore be secondary to complement activation. Both leukotriene $\mathrm{B}_{4}$ and anaphylatoxin $\mathrm{C}_{5} \mathrm{a}$ are highly chemotactic for granulocytes and are probably involved in the massive mucosal mobilization of such cells seen in ulcerative colitis; lysosomal enzymes and toxic oxygen radicals liberated from neutrophils may also attack the epithelium. The intraluminal and crypt staining for TCC and C3d in ulcerative colitis might have been induced by autoantibodies reacting with the $\mathrm{M}_{\mathrm{r}} 40 \mathrm{kDa}$ autoantigen in mucin, shedding of attacked cell-membranes, as well as being induced by the alternative activation pathway, perhaps secondary to epithelial damage (the latter may dominate in Crohn's disease).

Expression of the $M_{\mathrm{r}} 40 \mathrm{kDa}$ autoantigen by the colonic surface epithelium was often decreased in the surface epithelium in active ulcerative colitis and in patients with inactive disease of long duration. This suggests that IgG1. mediated complement attack might exert a selective pressure on the epithelium, thereby allowing cells with low expression of this antigen to survive. One of the consequences could be positive selection of dysplastic epithelium in ulcerative colitis. Such a putative mechanism would explain the increasing risk for developing colonic carcinoma after long disease duration. This possibility is testable and should be explored in the future. 


\section{REFERENCES}

1. Elson CO. The immunology of inflammatory bowel disease. In: Kirsner JB, Shorter RG, eds. Inflammatory bowel disease. Philadelphia. Lea \& Febiger, 1988:97-164.

2. Strober W, James SP. The immunologic basis of inflammatory bowel disease. J Clin Immunol 1986;6:415-32

3. Brandtzaeg P, Halstensen TS, Kett Y, et al. Immunobiology and immunopathology of human gut mucosa: Humoral immunity and intraepithelial lymphocytes. Gastroenterology, 1989;97:1562-84.

4. Gotze O, Miller-Eberhard HJ. Lysis of erythrocytes by complement in absence of antibody. J Exp Med 1970;132:898-903.

5. Bhakdi S, Tranum-Jensen J. Membrane damage by complement. Biochimica et Biophysica Acta 1983;737:343-72.

6. Bbakdi S. Functional and relevance of the terminal complement sequence. Bailliere's Clin Immunol Allergy 1988;2:363-85.

7. Mollnes TE, Lachmann PJ. Regulation of complement. Scand J Immunol 1988;27:127-42.

8. Garred P, Michaelsen TE, Aase A. The IgG subclass pattern of complement activation depends on epitope density, antibody and complement concentration. Scand J Immunol 1989;30:379-82.

9. Ishizaka T, Ishizaka K, Salmon S, Fudenberg $\mathrm{HH}$. Biologic activities of aggregated y-globulin. VIII. Aggregated immunoglobulin of different classes. J Immunol 1967;99:82-91.

10. Russell MW, Mansa B.

Complement-binding properties of human $\lg \mathrm{A}$ antibodies. Alternative pathway complement activation by plastic-bound, but not specific antigen-bound, IgA. Scand J Immunol 1989;30:175-83.

11. Ishizaka T, Sian OM, Ishizaka K. Complement fixation by aggregated IgE through alternative pathway. J Immunol 1972;103:848-51.

12. Müller-Eberhard HJ, Polly MJ, Calcot MA. Formation and functional significance of molecular complex derived from the second and the fourth component of human complement. J Exp Med 1967;125:359-80.

13. Becher JD, Alsenz J, Servis C, Myones BL, Lambris JD. Cell surface proteins reacting with activated complement components. Complement Inflamm 1989;6:134-65.

14. Gotze O, Miller-Eberhard HJ. Lysis of erythrocytes by complement in absence of antibody. J Exp Med 1970;132:898-903.

15. Fearon DT, Austen KF. Properdin: The alternative pathway of complement-A system for host resistance to microbial infection. N Eng J Med 1980;303:259-63.

16. Fearon DT, Austen KF. Activation of the alternative complement pathway with rabbit erythrocytes by circumvention of regulatory action of endogenous control proteins. J Exp Med 1977a;146:22-33.

17. Fearon DT, Austen KF. Activation of the alternative complement pathway due to resistance of zymosan-bound amplification convertase to endogenous regulatory mechanisms. Proc Natl Sci USA 1977b;74:1683-7.

18. Ratnoff VI, Fearon DT, Austen KF. The role of antibody in the activation of the alternative complement pathway. Springer Semin Immunopathol 1983;6:361-71.

19. Volanakis JE, Kaplan MH. Interaction of C-reactive protein complexes with the complement system. J Immunol 1974;113:9-17.

20. Claus DR, Siegel J, Petras K, Osmand AP, Gewurz H. Interaction of C-reacting protein with the first component of human complement. J Immunol 1977;119:187-92.

21. Aubert B, Chesne S, Arlaud GJ, Colomc MG. Antibody-independent interaction between the first component of human complement, $\mathrm{Cl}$, and the other membrane of Escherichia coli. Biochem J 1985;232:513-9.

22. Kovacsovics T, Tschopp J, Kress A, Isliker $\mathrm{H}$. Antibody-independent activation of $\mathrm{Cl}$, the first component of complement, by cardiolipin. J Immunol 1985;135:2695-700.

23. Bhakdi S, Tranum-Jensen J. C 5 b-9 assembly: average binding of one $\mathrm{C} 9$ molecule to $\mathrm{C} 5 \mathrm{~b}-9$ without poly-C9 formation generates a stable transmembrane pore. J Immunol 1986;136:2999-3005.

24. Zalman LS, Wood LM, Miller-Eberhard HJ. Isolation of a human erythrocyte membrane protein capable of inhibiting expression of homologous complement membrane channels. Proc natl Acad Sci 1986;83:6975-83.

25. Schönermark S, Rauterberg EW, Roelcke D, Löke S, Hänsch GM. Homologous species restriction in lysis of human erythrocytes. A membranederived protein with $\mathrm{C} 8$-binding capacity function as an inhibitor. J Immunol 1986; 136:1772-6.

26. Okada N, Harada R, Fujita T, Okada $\mathrm{H}$. A novel membrane glycoprotein capable of inhibiting membrane attack by homologous complement. Int Immunol 1989;1:205-8.

27. Meri S, Morgan BP, Davies A, et al. Human protectin (CD59), an 10,000-20,000 MW complement lysis restricting factor, inhibits $\mathrm{C} 5 \mathrm{~b}-8$ catalysed insertion of $\mathrm{C} 9$ into lipid bilayers. Immunology 1990;71:1-9.

28. Podack ER, Müller-Eberhard HJ. Isolation of human S-protein, an inhibitor of the membrane attack Complex of complement. J Biol Chem 1979;254:9908-14.

29. Murphy BF, Saunders JR, O'Bryan MK, Kirszbaum L, Walker IA, d'Apice AJF. SP-40,40 is an inhibitor of C 5 b- 6 initiated haemolysis. Int Immunol 1989;1:551-4.

30. Bhakdi S, Käflein R, Halstensen TS, Hugo F, Preissner KT, Mollnes TE. Complement S-protein (vitronectin) is associated with cytolytic membrane-bound C5b-9 complexes. Clin Exp Immunol 1988;74:459-64.

31. Medof ME, ldia K, Mold C, Nussenzweig $\mathrm{V}$. Unique role of the complement receptor CR1 in degradation of $\mathrm{C} 3 \mathrm{~b}$ associated with immune complex. J Exp Med 1982;156:1739-54.

32. Medicus GR, Melamed J, Arnaout MA. Role of human factor $\mathrm{I}$ and $\mathrm{C} 3 \mathrm{~b}$ receptor in the cleavage of surface-bound C3bi molecules. Eur J Immunol 1983;13:465-70.

33. Harrison RA, Farries TC, Northrop FD, Lachmann PJ, Davis AE. Structure of $\mathrm{C} 3 \mathrm{f}$, a small peptide specifically released during inactivation of the third component of complement. Complement 1988;5:27-32.

34. Fearon DT, Wong WW. Complement ligand-receptor interaction that mediate biological responses. Ann Rev Immunol 1983;1:243-71,

35. Lachmann PJ, Pangburn MK, Oldroyd RG. Breakdown of $\mathrm{C} 3$ after complement activation. Identification of a new fragment, $\mathrm{C} 3 \mathrm{~g}$, using monoclonal antibodies. J Exp Med 1982;156:205-16.

36. Garred P, Mollnes TE, Lea T, Fisher E. Characterization of a monoclonal antibody $\mathrm{MoAb}$ bH6 reacting with a neopitope of human $\mathrm{C} 3$ expressed on $\mathrm{C} 3 \mathrm{~b}, \mathrm{iC} 3 \mathrm{~b}$, and $\mathrm{C} 3 \mathrm{c}$. Scand J Immunol 1988;27:311-9.

37. Mollnes TE, Lea T, Harboe M, Tschopp J. Monoclonal antibodies recognizing a neoantigen of poly (C9) detect the human terminal complement complex in tissue and plasma. Scand J lmmunol 1985;22:183-95.

38. Ballard J, Sheiner M. Evidence of cytotoxicity in ulcerative colitis from immunofluorescent staining of the rectal mucosa. Lancet 1974:4:134-135. 
39. Gebbers JO, Otto HF. Evidence for local immune complexes in ulcerative colitis. Acta Gastro-Enterologia Belgica 1978;XLI:329-50.

40. Baklien K, Brandtzaeg P. Immunohistochemical localization of complement in intestinal mucosa. Lancet 1974;ii:1087-8.

41. Halstensen TS, Mollnes TE, Fausa 0, Brandtzaeg P. Deposits of terminal complement complex (TCC) in muscularis mucosae and submucosal vessels in ulcerative colitis and Crohn's disease of the colon. Gut 1989;30:361-6.

42. Halstensen TS, Mollnes TE, Brandtzaeg P. Persistent complement activation in submucosal blood vessels of active inflammatory bowel disease: Immunohistochemical evidence. Gastroenterology 1989;97:10-9.

43. Halstensen TS, Mollnes TE, Garred P, Fausa O, Brandtzaeg P. Epithelial Deposition of immunoglobulin G1 and activated complement (C3b and terminal complement complex) in ulcerative colitis. Gastroenterology 1990;98:1264-71

44. Halstensen TS, Mollnes TE, Garred P, Fausa O, Brandtzaeg P. Surface epithelium-related activation of complement differs in Crohn's disease and ulcerative colitis. Gut 1992;33:902-8.

45. Halstensen TS, Das KM, Brandtzaeg P. Epithelial deposits of immunoglobulin G1 and activated complement colocalize with the $\mathrm{M}_{\mathrm{r}} 40 \mathrm{kD}$ putative autoantigen in ulcerative colitis. Gut. (In press)

46. Das KM, Sakamaki S, Vecchi M, Diamond B. The production and characterization of monoclonal antibodies to human colonic antigen associated with ulcerative colitis: Cellular localization of the antigen by using the monoclonal antibody. J Immunol 1987;139:77-84.

47. Das KM, Vecchi M, Sakamaki S. A shared and unique epitope(s) on human colon, skin, and biliary epithelium detected by a monoclonal antibody. Gastroenterology 1990;98:464-9.

48. Brandtzaeg P. Mucosal and glandular distribution of immunoglobulin components. Immunohistochemistry with a cold ethanol-fixation technique. Immunology 1974;26:1101-14.

49. Huitfeldt HS, Brandtzaeg P. Various keratin antibodies produce immunohistochemical staining of human myocardium and myometrium. Histochemistry 1985;83:381-9.

50. Dahlbäck K, Lofberg H, Dahlbäck B. Localization of vitronectin (S-protein of complement) in normal human skin. Acta Dermatol Venereol 1986;66:461-7.

51. Brandtzaeg P, Rognum TO. Evaluation of tissue preparation methods and paired immunofluorescence staining for immunocytochemistry of lymphomas. Histochem ] 1983; 15:655-89.

52. Jefferis R, Reimer CB, Skavril F, et al. Evaluation of monoclonal antibodies having specificity for human IgG sub-classes: results of an IUIS/WHO collaborative study. Immunol Lett 1985;10:223-52

53. Halstensen TS, Mollnes TE, Brandtzaeg P. Terminal complement complex (TCC) and S protein (vitronectin) on follicular dendritic cells in human lymphoid tissues. Immunology 1988;65:193-7.

54. Koffler D, Minkowitz S, Rothman W, Garlock J. Immunocytochemical studies in ulcerative colitis and regional ileitis. Am J Pathol 1962;41:733-45.

55. Harrison WJ. Autoantibodies against intestinal and gastric mucous cells in ulcerative colitis. Lancet 1965;1:1346-50.

56. Wright R, Truelove SC. Autoimmune reactions in ulcerative colitis. Gut 1966;7:705-15.

57. Perlmann P, Hammarstrøm S, Lagercrantz R. Immunological features of idiopathic ulcerative colitis and Crohn's disease. Rendic Gasteroenterol 1973;5:17-28.

58. Marcussen H, Nerup J. Fluorescent anti-colon and organ-specific antibodies in ulcerative colitis. Scand J Gastroenterol 1973;8:9-15.

59. Hibi T, Toda $\mathrm{K}$, Hara A, et al. In vitro anticolonic antibody production by muscular or peripheral blood lymphocytes from patients with ulcerative colitis. Gut 1990;31:1371-6.

60. Snook JA, Lowes JR, Wu KC, Priddle JD, Jewell DP. Serum and tissue autoantibodies to colonic epithelium in ulcerative colitis, Gut 1991;32:163-9.

61. Boom BW, Out-Luiting CJ, Baldwin WM, Westedt M-L, Daha MR, Vermeer B-J. Membrane attack complex of complement in leukocytoclastic vasculitis of the skin. Presence and possible pathogenetic role. Arch Dermatol 1987;123:1192-5

62. Biesecker G. The complement SC5b-9 complex mediates adhesion through a vitronectin receptor. J Immunol 1990;145:209-14.

63. Halstensen TS. Complement deposits in inflammatory bowel disease. Gastroenterology 1990;99:1541-2.

64. Rothstein JL, Lint TF, Schreiber H. Tumour necrosis factor/cachectin. Induction of hemorrhagic necrosis in normal tissue requires the fifth component of complement (C5). J Exp Med 1988;168:2007-21.

65. Schindler R, Gelfand JA, Dinarello CA. Recombinant C5a stimulates transcription rather than translation of interleukin-1 (IL-1) and tumour necrosis factor: Translation signal provided by lipopolysaccharide or IL-1 itself. Blood 1990;76:1631-38.

66. Wakefield AL, Sawyer AM, Dhillon AP, et al. Pathogenesis of Crohn's disease: multifocal gastrointestinal infarction. Lancet 1989;ii:1057-62.

67. Ahrenstedt Ö, Knutson L, Nilsson B, Nilsson-Ekdahl K, Odlin B, Hällgren $\mathrm{R}$. Enhanced local production of complement components in the small intestine of patients with Crohn's disease. N Engl J Med 1990;322:1345-9.

68. McCready FJ, Bargen JA, Dockerly $\mathrm{MC}$, Waugh JM. Involvement of the ileum in chronic ulcerative colitis. New Engl J Med 1949;240:119-23.

69. Gustavsson S, Weiland L, Kelly KA. Relationship of backwash ileitis to ileal pouchitis after ileal pouch-anal anastomosis. Dis Colon Rectum 1987;30:20-8.

70. Takahasi F, Shah HS, Wise LS, Das KM. Circulating antibodies against human colonic extract enriched with a $40 \mathrm{kDa}$ protein in patients with ulcerative colitis. Gut 1990;31:1016-20

71. Okada N, Harada R, Fujita T, Okada $\mathrm{H}$. A novel membrane glycoprotein capable of inhibiting membrane attack by homologous complement. Int Immunol 1989;1:205-8.

72. Meri S, Morgan BP, Davies A, Daniels RH, Olavesen MG, Waldmann $\mathrm{H}$, Lachmann PJ. Human protection (CD59), an 10,000-20,000 MW complement lysis restricting factor, inhibits C5b-8 catalysed insertion of C9 into lipid bilayers. Immunology 1990;71:1-9.

73. Campbell AK, Morgan, BP. Monoclonal antibodies demonstrate protection of polymorphonuclear leukocytes against complement attack. Nature 1985;317:164-6.

74. Aluwihare APR. Electron microscopy in Crohn's disease. Gut 1971;12:509-18.

75. Thyberg J, Graf W, Klingenstrom P. Intestinal fine structure in Crohn's disease. Lysosomal inclusions in epithelial cells and macrophages. Virch Arch 1981;391:141-52.

76. Thayer WR, Chiodini R, Van Kruiningen HJ, Coutu J. Possible role of mycobacteria in Crohn's disease. In: Järnrot G, ed. Inflammatory Bowel Disease. New York: Raven Press, 1988b:95-100.

77. Stimler NP, Bach MY, Bloor CM, Hugli TE. Release of leukotrienes from 
guinea pig lung stimulated by C5adesArg anaphylatoxin. J Immunol 1982;128:2247-52.

78. Hartung HP, Hadding U, Bitter-Suermann D, Gemsa D. Stimulation of prostaglandin $\mathrm{E}$ and thromboxane synthesis in macrophages by purified C $3 \mathrm{~b}$. J Immunol 1983;130:2861-5.

79. Hartung HP, Bitter-Suermann D, Hadding U. Induction of thromboxane release from macrophages by anaphylatoxic peptide $\mathrm{C} 3 \mathrm{a}$ of complement and synthetic hexapeptide C3a 72-77. J Immunol 1983;130:1345-9.

80. Rutherford B, Schenkein HA. C3 cleavage products stimulate release of prostaglandins by human mononuclear phagocytes in vitro. J Immunol 1983;130:874-7.

81. Imagawa DK, Osifchin NE, Paznekas
WA, Shin ML, Mayer MM.

Consequence of cell membrane attack by complement: Release of arachidonate and formation of inflammatory derivates. Proc Nat Acad Sci 1983;80:6647-51.

82. Hänsch GM, Seitz M, Martinotti G, Betz M, Rauterberg EW, Gemsa D. Macrophages release arachidonic acid, prostaglandin $\mathrm{E}$, and thromboxane in response to late complement components. J Immunol 1984; 133:2145-50.

83. Adler S, Baker PJ, Johnson RJ, Ochi RF, Pritzl P, Couser WG. Complement membrane attack complex stimulates production of reactive oxygen metabolites by cultured rat mesangial cells. J Clin Invest $1986 ; 77: 762-7$

84. Ligumsky M, Karmeli F, Sharon P,
Uriel Z, Fortune C, Rachmilewitz D. Enhanced thromboxane $\mathrm{A} 2$ and prostacyclin production by cultured rectal mucosa in ulcerative colitis and its inhibition by steroids and sulfasalazine. Gastroenterology 1981;81:444-9.

85. Donowitz M. Arachidonic acid metabolites and their role in inflammatory bowel disease: An update requiring addition of a pathway. Gastroenterology 1985;88:580-7.

86. Lauritsen K, Laursen LS, Bukhave K, Rask-Madsen J. Effects of topical 5-aminosalicylic acid and prednisolone on prostaglandin E2 and leukotriene B4 levels determined by equilibrium in vivo dialysis of rectum in relapsing ulcerative colitis. Gastroenterology 1986;91:837-44. 


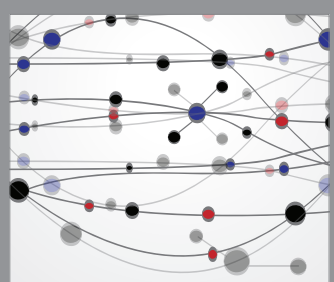

The Scientific World Journal
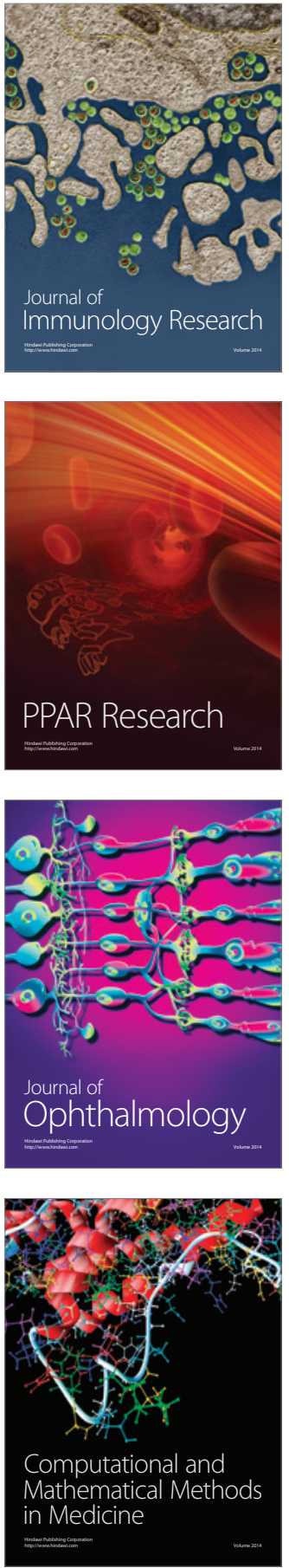

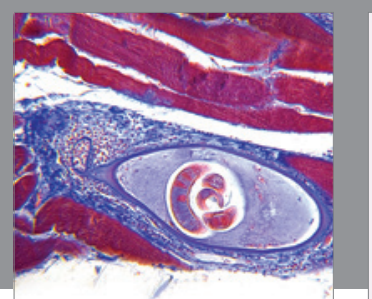

Gastroenterology Research and Practice

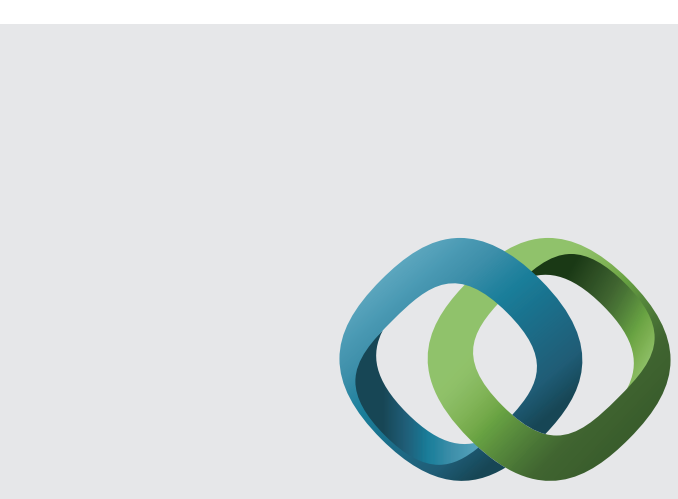

\section{Hindawi}

Submit your manuscripts at

http://www.hindawi.com
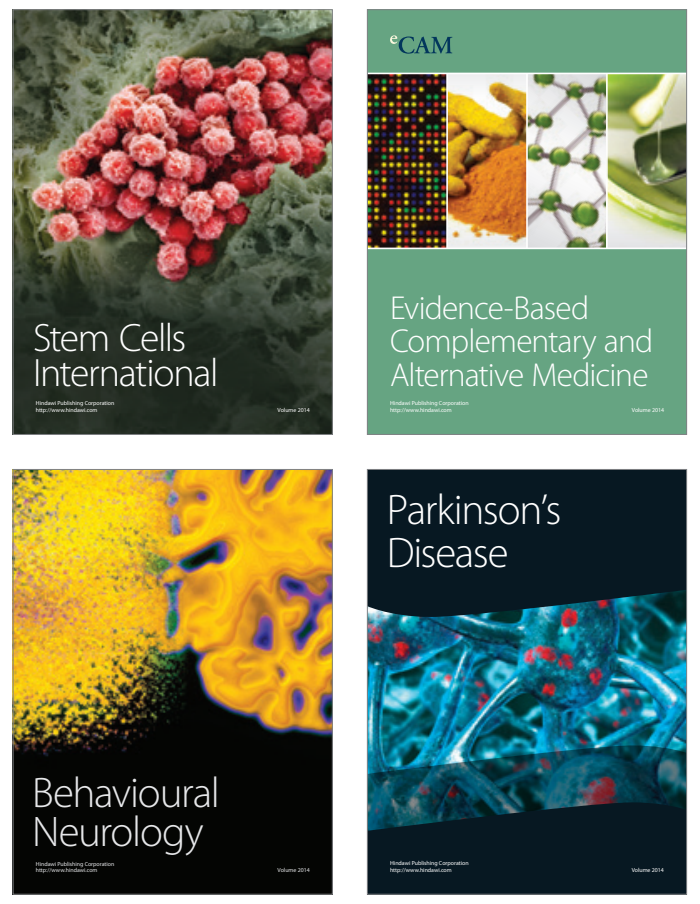
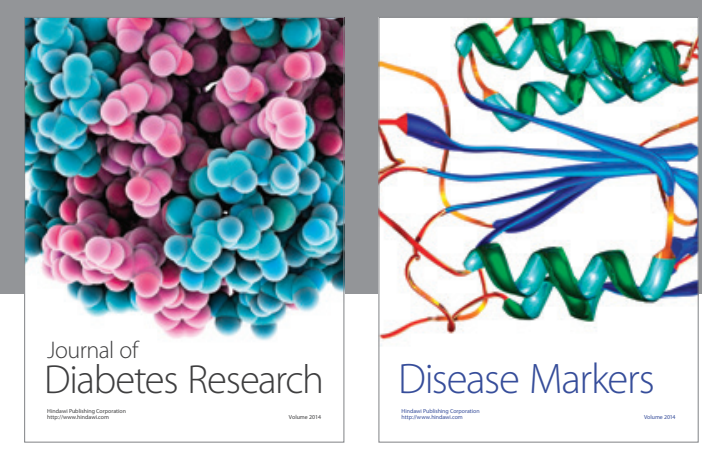

Disease Markers
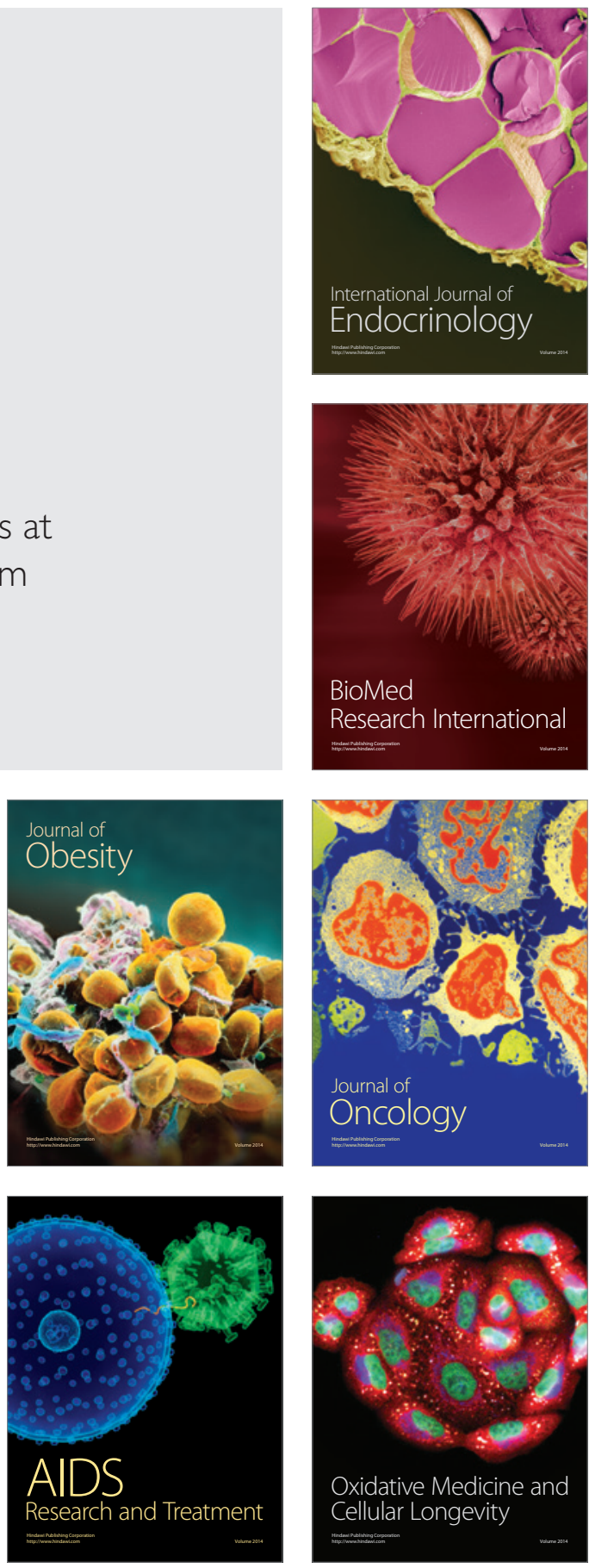